\title{
Stability Analysis of Catamaran Passenger Vessel with Solar Cell Energy in Calm Water
}

\author{
Dedi Budi Purwanto ${ }^{1}$, Aries Sulisetyono ${ }^{1}$, and Teguh Putranto ${ }^{1}$
}

\begin{abstract}
The use of solar energy as the driving force for the ship's tour seems to be a major theme in efforts to create a marine transportation that are environmentally friendly as part of the Energy Efficiency Design Index (EEDI) for the reduction of pollutant levels. The electrical energy generated by solar energy is not as much energy from fossil fuels so that the solar panel powered ship that can only be engaging with a limited range and speed.This type of catamaran hull design that has two symmetrical hull which allows to have an expansive deck, small boat barriers and good stability. The shape of the deck of the ship will contribute extents solar panels that can be utilized as a producer of power required at the time of calculation of powering the vessel. The analysis of the stability of the vessel performed numerically with reference to the IMO regulations requiring minimum value stability arm at certain angles. The output of this research is catamaran vessel that have battery, solar panel, electric motor moving with speed 5 knots.
\end{abstract}

Keywords—catamaran, solar panel, electric motor, battery.

Abstract Penggunaan energi matahari sebagai tenaga penggerak bagi kapal wisata tampaknya menjadi tema utama dalam upaya penciptaan alat transportasi laut yang ramah lingkungan sebagai bagian dari Energy Efficiency Design Index (EEDI) untuk pengurangan tingkat polutan. Energi listrik yang dihasilkan oleh energi matahari ini tidak sebesar energi dari bahan bakar fosil sehingga kapal yang bertenaga panel surya hanya mampu bergerak dengan jangkauan dan kecepatan yang terbatas. Penelitian ini melakukan studi hambatan, powering dan stabilitas kapal wisata yang beroperasi pada perairan tenang. Desain lambung ini bertipe katamaran yang memiliki dua lambung simetris yang memungkinkan mempunyai geladak yang luas, hambatan kapal yang kecil dan stabilitas yang baik. Bentuk dari geladak kapal akan memberikan kontribusi luasan panel surya yang dapat dimanfaatkan sebagai penghasil daya yang diperlukan pada waktu perhitungan powering kapal. Adapun analisa stabilitas kapal dilakukan secara numerik dengan mengacu pada peraturan IMO yang mensyaratkan nilai minimum lengan stabilitasnya pada sudut-sudut tertentu. Hasil yang didapatkan adalah kapal katamaran dengan perlengkapan baterai, panel surya, dan motor listrik yang mampu melaju dengan kecepatan 5 knot.

Kata Kunci-catamaran, solar panel, electric motor, battery.

\section{INTRODUCTION}

$\mathrm{I}$ n connection with the efficient use of energy, the world shipbuilding is currently vying to conduct a study on the design of ship design multihull which is believed to have a small obstacle compared with monohull [1]. One of the designs is the belle is a type of hull catamarans which is often used for tourist ships like the example in the tourist area Sarangan, Bedugul Lake and other water attractions with calm water conditions. As shown in Fig. 1 , the environmental conditions in the unspoiled tourist spot that needs to be maintained preservation of natural way to reduce or even eliminate air and water pollution.International Maritime Organization (IMO) has issued regulations on the limitation of air pollutants generated by a ship called the Energy Efficiency Design Index (EEDI).

All kinds of boats either single or double hull has a secure stability during metacenter point is above the center of gravity ships [2]. However, if the stability arm smaller or even negative, then the ship will be inverted for the reserve moment not there when the boat swerved certain angle. Therefore, IMO regulations already require the amount of arms that must be owned vessel stability so that safety and passenger comfort can be assured [3].

In calm waters, the determination within demihull on the small boats appeared to have a significant effect on the

${ }^{1}$ Dedi Budi Purwanto, Aries Sulisetyono, and Teguh Putranto are with Department of Naval Architecture and Shipbuilding Engineering, Institut Teknologi Sepuluh Nopember, Surabaya, 60111, Indonesia. E- total resistance of the ship. The volume of the submerged hull on the smaller catamarans of the single hull ships at the same weight. One of the factors that affect the weight of the boat is the material used where Fiber Reinforced Plastics (FRP) is a lightweight material that is suitable for boats who want a low loaded [4]. The use of a catamaran hull for tourist ships can increase speed by $30 \%$ of the speed of the single hull ships. It certainly would have an effect on driving energy use [5].

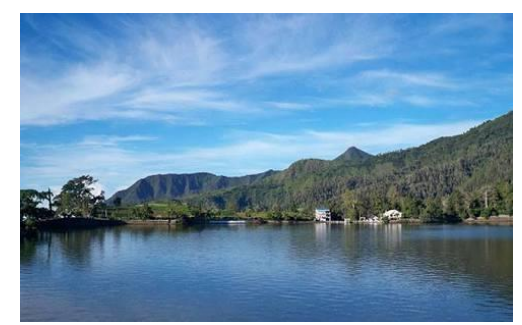

Figure 1. Sarangan lake

Energy use of fuel oil had started to be reduced in view of its natural resources cannot be an upgraded so that it is necessary to look for alternative energy is environmentally friendly [6]. Tourist boats with solar panels as an energy propulsion can be seen in Fig. 2 . Although the ship dynamics is not considered, the design of ship have to be analyzed the fluid structure interaction. It means that the shear force and bending moment caused 
by still water influence the dimension of profile and thickness of ship structure [7].

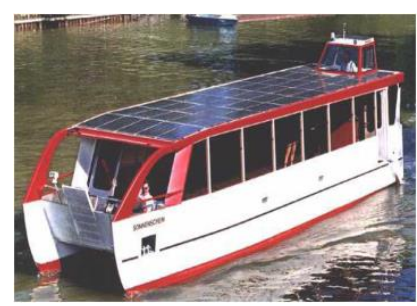

Figure 2. Catamaran vessel with solar cell energy

The types of ship hull, for example monohull and catamaran, provide some of advantages in the application. For the ship need the more space in main deck but the displacement of ship is small, catamaran vessel is appropriate to be applied for the ship design. The study of symmetrical and asymmetrical of catamaran vessel describe that the magnitude of resistance does not significantly affect in the low speed ship. For the high speed ship, the effect of interference between hulls is relatively affect the magnitude of resistance. If it is reviewed in aspect of the draft, symmetrical hull draft is smaller than the asymmetrical hull [8].

\section{METHOD}

This research is generally used by numerical method for stability and resistance analysis. This vessel has solar panel, battery, electric motor, and propulsion system to move the vessel. The source of energy comes from the solar energy that is converted to be electric energy to whirl the propeller. Fig. 3 shows that the flowchart conducted in this research.

\section{A. Catamaran Vessel Model}

Catamaran vessel have 2 (two) hulls symmetrically or not. In this research, the model uses catamaran symmetrically because from the previous research, this model provides advantages in aspect of stability and resistance.

\section{B. Stability Calculation and Analysis}

Intact stability calculation is taken to give the evidence that the ship is in seaworthiness condition. The calculation of length of metacenter is aim in this chapter. In order to obtain that magnitude, the Krylov I is used to answer the question about it. Equation 1 shows the Krylov I equation to determine the length of righting arm.

$$
l=\int M G d \theta
$$

The length of righting arm (GZ) could be used to check whether the stability of ship is accepted or rejected which it is regulated in the Intact Stability Code, IMO Regulation A. 749 (18). This regulation explains as follows:

1. $\mathrm{e}_{0.30} \mathrm{O} \geq 0.055 \mathrm{~m} . \mathrm{rad}$

2. $\mathrm{e}_{0.40 \mathrm{O}} \geq 0.09 \mathrm{~m} . \mathrm{rad}$

3. $\mathrm{e}_{30,40} \mathrm{O} \geq 0.03 \mathrm{~m} . \mathrm{rad}$

4. $\mathrm{h}_{30 \mathrm{O}} \geq 0.2 \mathrm{~m}$

5. $\mathrm{h}$ maximum at the $\phi \max \geq 25^{\circ}$

6. $\mathrm{GM}_{0} \geq 0.15 \mathrm{~m}$

C. Resistance Calculation
Because of ship in low speed, the van oortmerssen calculation for ship resistance is carried out. Ship is varied the speed included 0, 1, 2, 3, 4, and 5 knots. Equation 2 shows the Van Oortmerssen formula about ship resistance.

$$
\begin{aligned}
R_{T}= & \left(c_{1} f_{1}+c_{2} f_{2}+c_{3} f_{3}+c_{4} f_{4}\right) \Delta+ \\
& \left(C_{F}+\Sigma \Delta C_{F}\right)^{1 / 2} \rho V^{2} S
\end{aligned}
$$

in which,

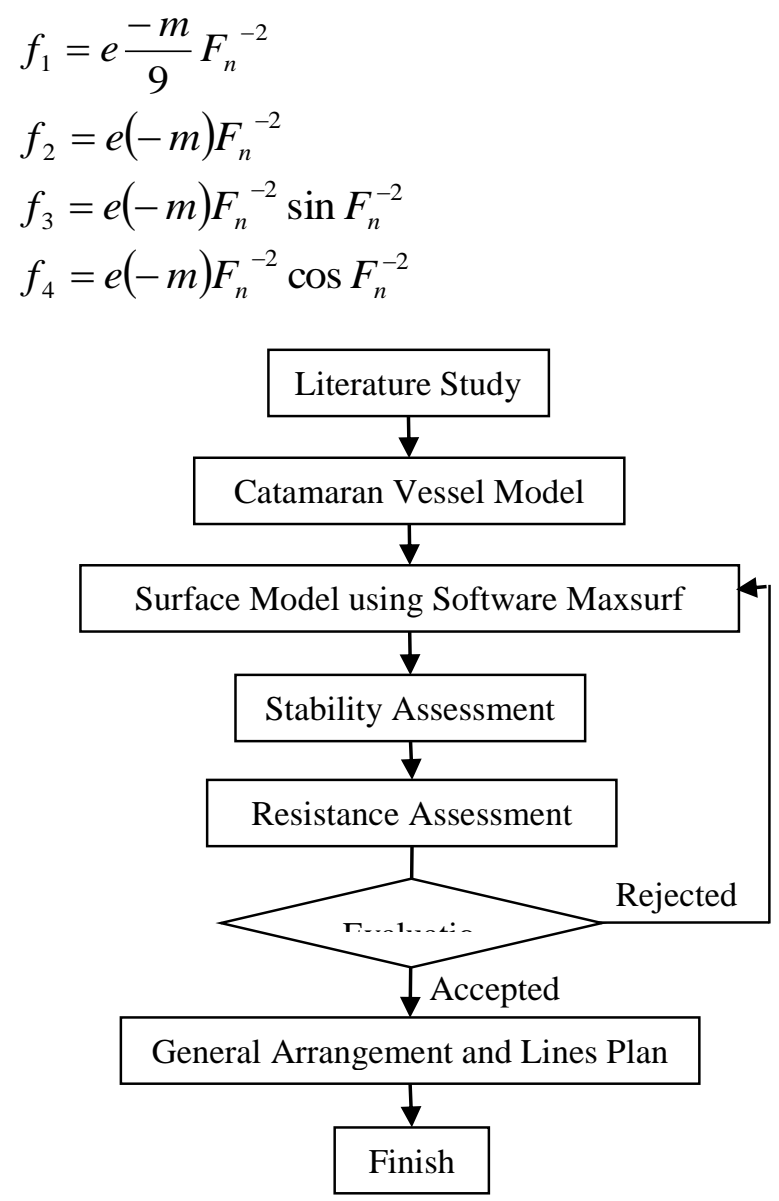

Figure 3. Flowchart

The total resistance of ship could be calculated by using Holtrop \& Mennen formula. This method consists of viscous and wave making resistance consideration. Equation 3 shows that the Holtrop formula.

$\mathrm{R}_{\mathrm{T}}=\frac{1}{2} * \rho * \mathrm{~V}^{2} * \mathrm{~S}_{\mathrm{tot}} *\left(\mathrm{C}_{\mathrm{F}}(1+\mathrm{k})+\mathrm{C}_{\mathrm{A}}\right)+\frac{\mathrm{R}_{\mathrm{W}}}{\mathrm{W}} \mathrm{W}$

Two methods are used to verify the result obtained from those methods. The magnitude of resistance could be used to estimate the main engine power of ship which the efficiency of shaft propeller is ignored because the propulsion system of this vessel is simple. So that the Effective Horse Power (EHP) obtained from multiplication between resistance and ship speed is same as the Break Horse Power (BHP).

\section{RESULTS AND DISCUSSION}

The catamaran vessel worked in this research have main dimension as follow:

Length of Waterlne (LWL) $\quad=4.4 \mathrm{~m}$ 
Breadth (B)

Draft $(\mathrm{T})$ at full load

$$
=2.6 \mathrm{~m}
$$$$
=0.5 \mathrm{~m}
$$

Freeboard $(\mathrm{Fb})$

Depth $(\mathrm{H})$

Capacity of Passenger

$=0.4 \mathrm{~m}$

$=0.9 \mathrm{~m}$

$=8$ persons

The position of solar panel is located above the vessel because it considers the absorb of solar energy. Fig. 4 shows the catamaran vessel for this research.

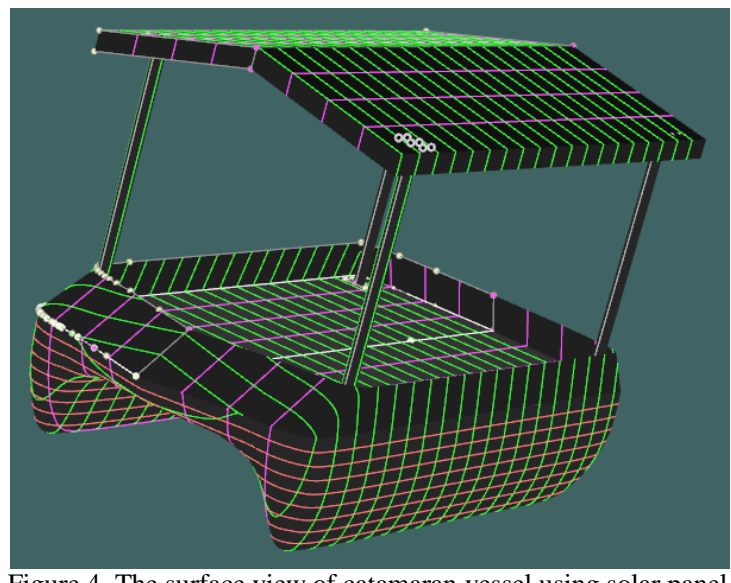

Figure 4 . The surface view of catamaran vessel using solar panel

Lines plan presents 3 (three) viewpoints that can be shown in Fig. 5. The views that can be shown are body plan, buttock plan, and half breadth plan. Figure 6 shows the general arrangement (GA) of this catamaran vessel. The height between main deck and solar panel is same with the average height of passenger about $180 \mathrm{~cm}$. The solar panel can serve as a protective passenger from sunlight.

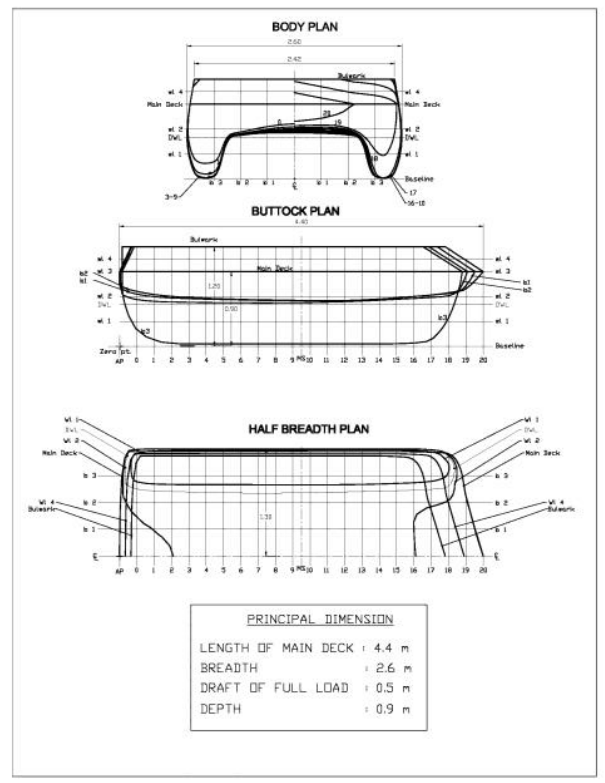

Figure 5. The lines plan of catamaran vessel using solar panel

To maintain the stability of this catamaran vessel, the position of seats is made parallel with side of ship. Furthermore, this position is created for comfort. Although this vessel does not sail in wave water, the aspect of comfortable still have to consider.

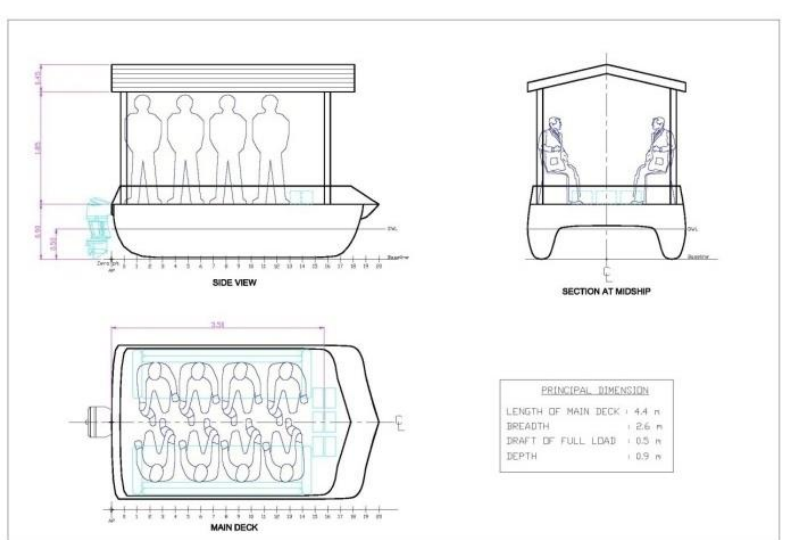

Figure 6. The general arrangement of catamaran vessel using solar panel

\section{A. Intact Stability Analysis}

Intact stability relates to the length of metacenter to gravity (MG) because this length affects the reserve moment of ship when the ship is in heel condition. Fig. 7 shows the graph of statics stability of this catamaran vessel. At the initial position with heel 0 degree, the GZ length is zero. At the moment where the heel is about 40 degrees, the GZ length is in the maximum value $0.4 \mathrm{~m}$. the empty condition provides such result.

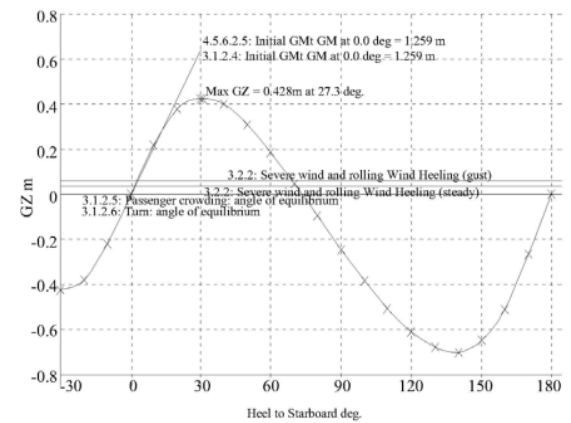

Figure 7. The GZ curve at no passenger condition

Figure 8 shows the graph of GZ curve for full load condition. The GZ maximum is occurred in the heel angle about 35 degrees. After 35 degrees, the GZ length decreases significantly to zero value. This is critical point where the ship stability changes to be an unstable condition.

TABLE 1.

THE SHIP STABILITY ANALYSIS BASED ON THE LOAD CASES COMPARED BY IMO CRITERIA

\begin{tabular}{lllll}
\hline \hline Parameter & LC1 & LC 2 & IMO & Criteria \\
\hline $\mathrm{e}_{0.30} \mathrm{O}$ & 0.21 & 0.63 & $\geq 0.055$ & Accepted \\
$\mathrm{e}_{0.40} \mathrm{O}$ & 0.28 & 0.83 & $\geq 0.09$ & Accepted \\
$\mathrm{e}_{30,40} \mathrm{O}$ & 0.07 & 0.20 & $\geq 0.03$ & Accepted \\
$\mathrm{h}_{30} \mathrm{O}$ & 0.40 & 1.20 & $\geq 0.2$ & Accepted \\
$\phi \max$ & $30^{0}$ & $33^{0}$ & $\geq 25^{0}$ & Accepted \\
$\mathrm{GM}_{0}$ & 1.26 & 4.20 & $\geq 0.15$ & Accepted \\
\hline \hline
\end{tabular}




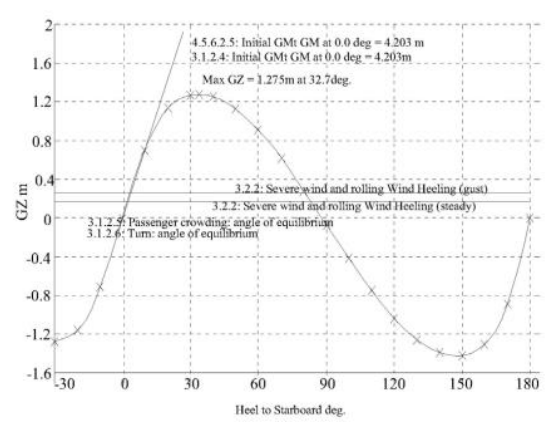

Figure 8. The GZ curve at full load condition

This condition can cause the ship capsize. Because this catamaran vessel does not sail in the wave water condition, the ship capsize caused by wave is impossible happened. Possible ship sinking is caused by the position or distribution of passenger focused on the one side of ship.

Table 1 shows that the ship stability analysis of two load cases. The load cases consists of no passenger (LC1) and full load (LC2). From the result, each of parameter has accepted criteria for each load cases. If there is a parameter that is not fulfills the IMO regulation, the criteria would be rejected because it means that the ship would be fail.

\section{B. Resistance Analysis}

There are some methods for calculating the ship resistance. One of method for calculating the resistance is Van Oortmerssen Method. This method is suitable for small displacement ships which have involved the main resistance components such as viscous resistance and wave making resistance. This method is same as Holtrop Method. The result of two methods is compared to show that the pattern of graph is relatively same.

Figure 9 shows the graph indicating the relation between total resistance and ship speed using Van Oortmerssen and Holtrop Method. The greater resistance is occurred in the faster of ship speed. The maximum of total resistance is about $1.8 \mathrm{kN}$ in ship speed 5 knots.

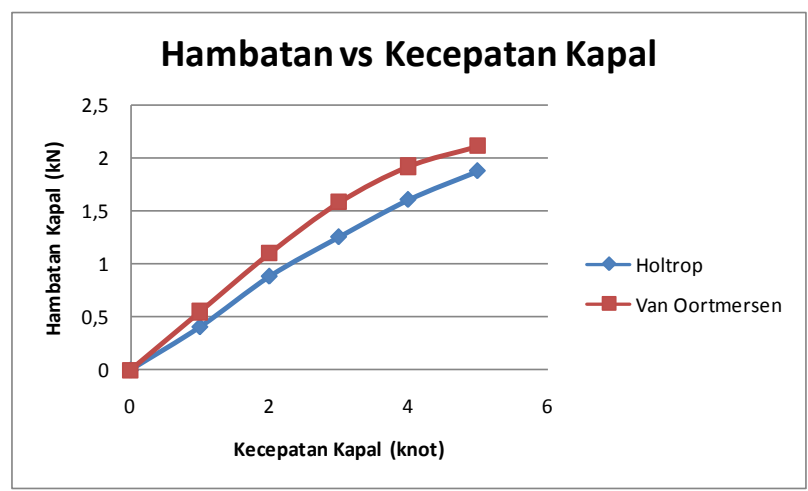

Figure 9. Total resistance in various of speed at catamaran vessel

Need main engine power depends on the total resistance of ship. For the total resistance is $1.5 \mathrm{kN}$, the main engine power needed for ship speed 5 knots is $3.85 \mathrm{~kW}$. The specification of main engine is by using electric motor because the power obtained comes from solar energy. The magnitude of electric motor power is 2000 Watt so that is needed two electric motors.

\section{CONCLUSION}

The conclusion of this research can be concluded as follows:

1. The position of metacenter that indicates stability of ship is still located above gravity point either full load condition or empty condition. The maximum GZ at the full load condition is about $1.2 \mathrm{~m}$ and the one at empty load condition is about $0.4 \mathrm{~m}$;

2. The vessel can be operated because the electric motor power is greater than the resistance. From the result and discussion, the resistance is about $2.043 \mathrm{kN}$ in maximum speed, but the electric motor is about 2000 Watt;

3. The greater resistance is followed with the faster of ship speed. By the van oortmerssen method, the resistance calculation is able to provide the magnitude for low speed.

\section{ACKNOWLEDGEMENT}

Researcher would like to express the appreciation for LPPM ITS that have given the fund and support through Penelitian Pemula Grant in 2016.

\section{REFERENCES}

[1] Jasionowski, A., Vassalos, D., "Ship Vulnerability to Flooding", Safety At Sea Ltd., The Ship Stability Research Center, University of Glasgow Strathclyde, UK, 2009.

[2] Bhattacharyya, R., "Dynamics of Marine Vehicles," John Wiley and Sons, New York, USA, 1978.

[3] Danisman, D. B., "Reduction of Demi-Hull Wave Interference Resistance in Fast Displacement Catamarans Utilizing an Optimized Centerbulb Concept", Journal of Ocean Engineering, Vol. 91, pp. 227-234, 2014.

[4] Date, J., Turnock, S. R., 1999, A Study into the Techniques Needed to Accurately Predict Skin Friction using RANS Solvers with Validation against Froude's Historical Flat Plate Experimental Data, Ship Science Report No. 114, Department of Ship Science, the University of Southampton, UK, March.

[5] Lee, S. H., Lee, Y. G., Kim, S. H., "On the Development of a Small Catamaran Boat", Journal of Ocean Engineering, Vol. 34 (14), 2007.

[6] Pujiwat, R., "Analisa Teknis dan Ekonomis Perencanaan Water Bus Dengan Tenaga Surya di Banjir Kanal Barat Jakarta", Skripsi, Jurusan Teknik Perkapalan, Institut Teknologi Sepuluh Nopember, 2008.

[7] Purwanto, D. B., Utama, I. K. A. P., “Kajian Pengembangan Kapal Wisata Berbasis Energi Alternatif: Kombinasi Layar dan Panel Surya", Jurnal Ilmu Pengetahuan dan Teknologi Kelautan, Vol. 12, No. 1, Universitas Diponegoro, 2015.

[8] T. Putranto and A. Sulisetyono, "Analisa Numerik Gerakan dan Kekuatan Kapal Akibat Beban Slamming Pada Kapal Perang Tipe Corvette", Jurnal Ilmu Pengetahuan dan Teknologi Kelautan, Vol. 12, No. 3, Universitas Diponegoro, 2015.

[9] Setyawan, D, "Development of Catamaran Fishing Vessel", IPTEK Journal, Institut Teknologi Sepuluh Nopember, 2010. 